\title{
Does the Indonesian banking architecture matter substantively? The case of improving understandability and comparability
}

\author{
Sumiyana Sumiyana \\ Department of Accounting, \\ Faculty of Economics and Business, University of Gadjah Mada, \\ Indonesia \\ sumiyana@ugm.ac.id
}

ORCID 0000-0002-1518-9681

\section{Tri Hanani}

Master of Science and Doctorate Programmes,

Faculty of Economics and Business, University of Gadjah Mada,

Indonesia

tribanani1024@gmail.com

Abstract. This research investigates the constructive validity of Indonesian Banking Architecture (IBA), especially regarding the structure of international, national, local development, and rural credit banks. It impeaches the existent structure, which is unclear as to the earning power, capacity, investment scalability, growth opportunities, and the discount rate of banks. This study argues that the IBA's structure concentrates exclusively on the classification of assets' size and legal form. It examines the old IBA's structure using mean comparison in differentiating among banks' book levels. This study found that the IBA' structure does not matter substantively. It recommends that the current IBA's structure be transformed into a new matrix structure similar to the GE and BCG Models, including at least two measurement factors. This new matrix would result in a more meaningful description and ensure the understandability and comparability of the Indonesian banking industry. Regulators could use such structure to shape the banking industry more inclined to adaptive structuration, dynamic capability, and business agility.

Keywords: banking architecture, modern measurement, adaptive structuration, dynamic capability, business agility.

JEL Classification: G24, E58 


\section{INTRODUCTION}

This study investigates the Indonesian Banking Architecture (IBA) structure that arranges international, national, local development, and rural credit banks, respectively. The attention the Indonesian government pays to the banking industry's resilience has increased since the financial 1997-1998crisis. The government made a considerable effort to restructure Indonesian banks in the post-crisis period by creating the IBA in 2004 (OJK, 2017). Within the IBA's system, Bank Indonesia and the Indonesian Government set a target to strengthen Indonesia's banking capital within the subsequent 10 to 15 years. This study highlights that the IBA has a single vertical axis structure and impeaches this IBA due to this single-axis system. This study argues that the most logical structure should be at least a two-axes, i.e. horizontal and vertical. Then, it would explain and describe the banking industry in terms of comparability and understandability.

The novelties that this research offers comprise the following argumentations. First, this study argues that having only a single vertical axis or factor means the IBA structure is an error because it does not provide a sufficient degree of comparability and understandability. The logical construction of this structure should combine at least two elements formed in two dimensions (Bhatia, 1997; Hax \& Majluf, 1983; Higham, 2008). Admittedly, three axes would make for an even more comprehensive system. However, most users have difficulty perceiving what such a structure would entail. Most structuralists form the social life phenomenon in two dimensions to ensure comprehensibility (Coad \& Herbert, 2009; Englund \& Gerdin, 2014; Giddens, 1984). This study posits what structuralists (Coad \& Herbert, 2009; Giddens, 1984) recommended that all the users of this IBA's structure get their practical insights in comparing and understanding these banks. Second, this study proposes a new structure that would reflect a bank's dynamic position in an industry dependent on its performance and risks. In the matrix's structure, a bank, as a member of the new IBA's structure, could move from one cell to another from year to year. Inversely, the current IBA's structure occupies a bank at a fixed level with either the IBA's book-1, $-2,-3$, or -4 purposively. The dynamic structure for the members of a matrix cell is better than the IBA's fixed one because the new IBA structure could support robust competition (Hax \& Majluf, 1983; McKensey, 2008; Thomson, 2018). In other words, this research proposes that the new IBA structure could facilitate a bank with its designation and performance periodically. This means that a bank would not always be categorized as a local development bank, as has been the case with the existent IBA thus far. Instead, the bank could move into a different cell as recommended by an improved IBA.

Third, this study argues that a bank's performance is internally dependent on its operating and financing leverage. In other words, it explains that bank size cannot determine its performance due to its operating and financing leverages (Bradshaw et al., 2006; Cohen \& Lys, 2006; Weiss et al., 2008). It means that size does not matter. A bank's financial management is constructed from the costs of its funding, which are the savings and deposits of its customers, debts from creditors, and investment by the owners. Moreover, a bank processes its internal business activities for labour and overhead costs, which create a net interest margin (Weiss et al., 2008). A big bank usually faces high labour and overhead costs because it must maintain its assets and pay high salaries to managers with good reputations. Meanwhile, a small bank has few facilities and lower labour costs. Consequently, a bank's risk is not because of its size but because of its business activities, costs of funds, labour, and overhead costs, and others.

To achieve this study's mission, reference is made to the structuration theory (Englund \& Gerdin, 2014; Giddens, 1984), the social comparison theory (Liu et al., 2018; Stiles \& Kaplan, 2004; Suls et al., 2002), and the matrix's function (Higham, 2008). This research uses the structuration theory to criticize the current IBA's structure and transform it into a new one. The structure functions are good when each user can find its occupancy quickly, and then it can compare it with other similar ones. This means that the users efficiently perceive their occupancies in the industry where they have distorted their cognitive flows when they seek to 
transform themselves and move into a higher position. The social comparison theory is used to show the benefit of using a new IBA structure. It explains the future comparability among banks because of their positions in the matrix. The last is the matrix's function: constructing the cell arrays for the new IBA structure. This study also considers a combination of structuration and the social comparison theory so that a member could be dynamically occupied in this structure, comparing each bank's performance in the industry. This matrix should contain a combination of two axes, which are horizontal and vertical. Furthermore, it refers to the modern measurements used in financial accounting (Chen \& Zhang, 2007; Zhang, 2000), which are the earning power, capacity, investment scalability, growth opportunities, and the discounted cost of capital. These measurements are also used to investigate the robustness of this study's research design.

This study expects to make various contributions after completing all the statistical analyses. The first contribution is the replacement of the structure of the old IBA with a new one. The authors promulgate new knowledge about the structure of the banking industry in Indonesia. The new knowledge is primarily about the solid structure of the new IBA system, which should be disseminated to all the banks in the industry. This knowledge is that the new IBA's structure comprises two axes, at 90 degrees from each other, which help all the users to understand and consecutively compare each bank in the banking industry. The new IBA structure supersedes the current one based on size, features, and legal status. The current IBA structure has ranked all banks as rural credit banks, local development banks, national banks, or international banks. Meanwhile, the new IBA structure displays all banks by their "structural-potential" and "structurein-use" (DeSanctis \& Poole, 1994; Poole \& DeSanctis, 1990; Scott Poole \& DeSanctis, 1992). This new IBA means that, for example, a rural credit bank could be positioned close to an international bank due to its earning power and growth opportunities.

The second contribution is an awareness process for the regulators, the banks' executive officers, and academicians so that they know that there is a need for a dynamic structure so that each member would be able to place itself in this structure. The dynamics refer to each bank's performance and its periodical changes. This dynamics also means that the new structure would be relevant for measuring the earning power, capacity, investment scalability, growth opportunities, and discounted cost of capital (Chen \& Zhang, 2007; Zhang, 2000). Consequently, the new IBA structure helps all the banks in Indonesia to compete with each other. This study argues that it does not ignore all the existing measurements, such as the capital adequacy ratio, return on assets or equities, lending to deposit ratio, operating costs - operating revenues, and others. However, it supports the new IBA structure with the matrix function for performance evaluations and measurements. It furthermore could exhibit forward-looking values due to additional unique measures and dynamic structures.

Hereafter, this study's subject is discussed as follows. In Section 2, the authors present the structuration theory, the social comparison theory, the matrix's function, and new additional measurements for banks' performance and risk. Here, the authors argue the need for a new structure for the IBA, which empowers its understandability and comparability. Section 3 discusses the research method, which includes the sampling method and statistical tests. The most strategic methods are the two phases of the testing of the hypotheses. Section 4 discloses all the statistical results, the discussion and analysis, and the research findings. Here, this study argues that the current IBA structure should be transformed into a new one. Doing so would create some benefits for the Central Bank of Indonesia and the Indonesian Financial Service Authority (FSA). Finally, Section 5 presents summaries, limitations, and suggestions for potential future research. 


\section{LITERATURE REVIEW AND HYPOTHESES DEVELOPMENT}

\subsection{Structuration theory}

The structuration theory developed the concept of structural duality, where the structure can be social networking accompanied by its possible result, and it could reproduce some of the human or organizational practices (Coad \& Herbert, 2009). The social structure refers to the concept developed by Giddens (1984), which is different from mechanical systems. Social structure is a table pattern for the social system which underlies what happens when an agent interacts with another (Englund \& Gerdin, 2014; Giddens, 1984). The structure can be the rules and resources that are the property of the social system (Giddens, 1984). Structuring, meanwhile, occurs when the social system produces structural changes continuously (Giddens, 1984). Humans (agents) always gather knowledge during interaction with other people, which accumulates to become their capital in their structuration process (Coad \& Herbert, 2009). In more detail, Giddens (1984) divided the human capital obtained from the structure into three types, which are interpretative schemes, facilities, and norms. Giddens (1984) also divided the structure into three types: signification, domination, and legitimation. The signification structure provides the general interpretative scheme needed for communication; the legitimation structure provides the norms required to impose sanctions; and the domination structure offers the facility to exercise power (Englund \& Gerdin, 2014; Giddens, 1984).

The structuration theory has been widely used to explain social and organizational life phenomena in accounting, banking, and other financial systems. Coad and Herbert (2009) demonstrated that the structuration theory has great potential to explain accounting and managerial phenomena more flexibly. This study posits Giddens (1984) and Coad and Herbert (2009), which are used to transform and to change the IBA. The IBA shapes the Indonesian banking structure into four categories on a single axis. This structure is somehow confusing to expert bankers due to the singularity of its axis. Based on the structuration theory, the IBA's structure will continue to change along with the transformation process in life. The mission and objective of this study are to transform the current structure of the IBA into a new, more comprehensive one.

\subsection{Social comparison theory}

The social comparison theory explains that individuals conduct self-evaluations to compare themselves to others when they want to accomplish their mission, goal, or objective (Festinger, 1954). Suls et al. (2002) and Ogden and Venkat (2001) suggested specifically that social comparisons are part of the process of an individual's self-evaluation, which is used to improve their self-enhancement. Goethals (1986) offers another explanation; he states that individuals conduct social comparisons when referring to a group's abilities. The use of social comparisons has become increasingly complex because individuals play diverse roles when using information. Social comparisons are used by an individual to evaluate past and current results and predict the prospects for future outcomes (Stiles \& Kaplan, 2004; Suls et al., 2002). This study considers that social comparisons would be helpful in life, allowing someone to characterize other people's behaviour in some conditional situations (Liu et al., 2018). It takes into account that a bank is like individual behaviour.

This study posits the social comparison theory, which evaluates the weaknesses in the structure of the current IBA. Then, it creates a new IBA structure that could be implemented prospectively. In other words, this study considers the social comparison theory to compare the performance, competency, abilities, and limitations of banks (Liu et al., 2018; Stiles \& Kaplan, 2004). It assumes that banks are individuals in society. This study argues that individuals will be influenced in their cognitive orientation by continuum points, which are ambiguations. It means that a bank may advance its performance, which should not be possible 
in this continuum level, but it could use vectors. Therefore, this study develops a new IBA structure that would be very comparable and easily understood.

\subsection{Matrix function}

In mathematics, a matrix can be defined as a rectangular array. Its function is to map one structure into another one. This study summarizes the operation of a matrix based on Higham (2008). The first is the primary function of the matrix structure, which is used to infer how an array becomes convergent due to its correspondence. It means that, from complex phenomena, a matrix could converge into a simple argument or generalization (Higham, 2008). The second is the essential function of the analytic formula, which is used to construct or develop multiple scalar uses (Bhatia, 1997; Higham, 2008).

McKinsey (2008) used a matrix function to develop and then implement the General Electric Model. In this model, the structure is composed of two-dimension (axes), which are industrial attractiveness (horizontal axis) and business unit strength (vertical axis) (Aramand \& Valliere, 2012; Thomson, 2018). This structure explains that a business unit in one position could be directed to move forward and up (vectoring) by whatever route the chief executive and management requirements. Whether this model is used for the new IBA structure or not, this study infers that a bank in its industrially coordinated position is easily understood if it has a simple strategy. In other words, a bank could be directed to move forward and up (vectoring) to make it operate more efficiently, with less risk, and better overall performance. It, therefore, means that this new IBA structure can be understood and compared, whether it takes into account the general electric model or not.

\subsection{IBA current structure}

IBA is a blueprint, landscape, stratification, and mapping for financial institutions, structures, supervision, regulation, and other supporting institutions. The collapse of the banking industry after the monetary crisis of 1997 proved that Indonesia, as an emerging country, was unable to overcome external shocks. OJK (2017) suggested that a valuable and comprehensive banking architecture was expected to support infrastructure for the stability of the overall financial system. The mission and vision of the IBA itself are to achieve a healthy, efficient, and robust banking system and to create a stable financial system to encourage national economic growth (OJK, 2017). The IBA has six pillars that make up the banking structure: a sound banking structure, an effective regulatory system, an independent and effective supervision system, a strong banking industry, adequate supporting infrastructure, and consumer protection (OJK, 2017). This study argues that the IBA's programs strengthen the national banking structure, increasing its capital over the next 10 to 15 years (OJK, 2017). In addition, the IBA is expected to create a more optimal banking structure by encouraging the presence of international banks, national banks, local development banks, and rural credit banks.

Banking supervision has shifted from the Central Bank of Indonesia to the Indonesian Financial Services Authority (FSA). The Indonesian FSA explains that the current IBA, within the next 10 to 15 years of its implementation, is expected to create a more optimal capital structure nationally, which will be structured as follows:

1. Book -4: International banks with 2 to 3 banks operating. Each bank has a capital of more than IDR 50 trillion.

2. Book -3: National banks with 3 to 5 banks operating nationally. Each bank should have a capital of between IDR 10 to 50 trillion.

3. Book -2: Local development banks with 30 to 50 banks focusing on specific business segments and capital between IDR 100 billion and 10 trillion. 
4. Book -1: Rural credit banks with limited business activities with a capital of under 100 billion IDR.

Besides measuring the levels, the current IBA structure measures a bank's performance and risk using assets-liabilities management with specific primary indicators (OJK, 2017). First, the current ratio (CR) measures the level of short-term bank liquidity used to ensure the bank's business operations run smoothly. Second, (McGoldrick \& Andre, 1997) utilize the loan to deposit ratio to assess a bank's long-term liquidity, especially in terms of the entire amount of its credit loans compared to its financial funding. Third, the capital adequacy ratio (CAR) measures the capital adequacy risk of banks in supporting assets that have risks. Fourth, return on assets (ROA) shows the effectiveness of the asset management carried out by the bank to generate profits from its business operations. Then, ROE, or the return on equities (Zeitoun \& Warner, 2006), shows the level of effectiveness of the bank's capital management. Fifth, operating costs to operating revenue (OC-OR) measures the power of the bank to control operational costs, which are matched with the operating income. Finally, non-performing loans (NPL) is a health indicator of the assets' quality, which measures the banks' ability and adaptability to manage future potential losses.

Therefore, this research considers the kind measurements to examine this current IBA's levelled structure. Nevertheless, whether the examination is correct in presenting the IBA's structure, Book -1 has lower performance and a higher risk than Books $-2,-3$, and -4 , but it is still confusing due to the single axis. Moreover, the current IBA structure does not induce forward-looking information into the performance or risk measurements. Therefore, this study continues in its expectation of inducing this forward-looking information and modern financial accounting.

\subsection{Measurements of modern financial accounting}

Zhang (2000) and Chen and Zhang (2007) argued that the value relevance of fundamental accounting information focuses on measurements of earning power, capacity, investment scalability, growth opportunities, and the discounted cost of capital. This study posits that the measure used by Chen and Zhang (2007) for the validity of the current IBA's measurements concentrates on asset-liabilities management. The measure considers that the performance and risk measurements are similar to those of the present IBA. However, the measures based on modern financial accounting make their formulation with a differential calculation, which considers forward-looking information. Moreover, the new measurements are used to construct the structure of the new IBA, which has better understandability and comparability.

This study considers all measurements based on Zhang (2000) and Chen and Zhang (2007). Earning power is resource inflows characterized by asset enhancement, decreasing liabilities, or combining both in an accounting period. It means that a bank could maintain its capital or assets. Earning power could be used to measure either organizational or the chief executive officer performance. Earning power is used by modern financial accounting systems because it can be determined systematically from all the previous earnings of the bank. Capacity refers to a bank's equity capital, which generates potential future income for the firm. Investment scalability relates to a bank's assets used to fund bank activities to gain future profits. These two measurements show a different perspective of bank investments. Capacity is the net residual value for investors, but investment scalability is for the bank itself, including its debts. Growth opportunities measure a bank's ability to make incremental sales in the lead periods. It means that a bank is free from its bankruptcy process. On the other side, investors and creditors perceived growth opportunities as forwardlooking information as prospective information. The latest is the discounted cost of capital for a bank. It has a multiplier effect for both a bank's assets and equities. It is also called the discount factor as it leverages the bank to be more efficient in its operations. 
This research considers all the measurements used in modern financial accounting (Chen \& Zhang, 2007; Zhang, 2000) to construct the new IBA structure and examine the validity of the current one. Of course, this means that modern financial accounting measurements will probably show different results. However, the results support understandability and exhibit robustness when tested without ignoring the measures of the current IBA structure. Furthermore, this study demonstrates that modern measurement could either complement or enhance this structure.

\subsection{Hypotheses development}

This study has highlighted the use of the current IBA structure with levelling of the Book -1 (rural credit banks), Book -2 (local development banks), Book -3 (national banks), and Book -4 (international banks). The IBA stated that a higher book value would perform better than a lower one. This study demonstrates that banks listed in Book -4 perform better than those in the other books. The performance measurements are CR, LDR, ROA(E), CAR, OE-OR, and NPL. In other words, higher book value should show better performance and lower business risk. If the higher value banks perform better than the lower value ones, the current IBA structure is valid. Otherwise, the logic is inverted for the banks' risks. From the validity perspective of the IBA's structure, this study formulates Hypothesis H1 with six kinds of performance and risk, as listed below.

H1a: International banks have a higher CR than national ones, which have a higher CR than local development ones, which have a higher CR than rural credit ones.

H1b: International banks have a higher LDR than national ones, which have a higher LDR than local development ones, which have a higher LDR than rural credit ones.

H1c: International banks have a higher ROA(E) than national ones, which have a higher ROA(E) than local development ones, which have a higher ROA(E) than rural credit ones.

H1d: International banks have a higher CAR than national ones, which have a higher CAR than local development ones, which have a higher CAR than rural credit ones.

H1e: International banks have a lower OE-OR than national ones, which have a lower OE-OR than local development ones, which have a lower OE-OR than rural credit ones.

H1f: International banks have a lower NPL than national ones, which have a lower NPL than local development ones, which have a lower NPL than rural credit ones.

This study has taken into account the same logical reasoning behind Hypothesis H1. Hypothesis H2 is constructed based on modern financial accounting's measurements. This study re-proposes that banks listed in Book -4 perform better than those listed in the other books. The performance measurements are earning power, capability, investment scalability, growth opportunities, and the discounted cost of capital. The measure used by this study ascertains that the current IBA's measurement structure has no measurement bias. The reasoning behind Hypothesis H1 is that the IBA's structure would be valid, regardless of whether these performance comparisons among the higher book values and the banks' lower ones are correct. Otherwise, whether this study found these inverted pieces of evidence or not, the IBA's structure is not valid. In the development of these hypotheses, this research deals with the validity of the IBA's structure. It then designs Hypothesis $\mathrm{H} 2$ with five kinds of performances and risks, as seen below.

H2a: International banks have higher earning power than national ones, which have higher earning power than local development ones, which have higher earning power than rural credit ones. 
H2b: International banks have a higher capacity than national ones, which have a higher capacity than local development ones, which have a higher capacity than rural credit ones.

H2c: International banks have higher investment scalability than national ones, which have higher investment scalability than local development ones, which have higher investment scalability than rural credit ones.

H2d: International banks have higher growth opportunities than national ones, which have higher growth opportunities than local development ones, which have higher growth opportunities than rural credit ones.

H2e: International banks have lower discounted costs of capital than national ones, which have lower discounted costs of capital than local development ones, which have lower discounted costs of capital than rural credit ones.

\section{RESEARCH METHOD}

\subsection{Data collection}

This study collects data from the Bureau van Dijk's OSIRIS database, the Financial Services Authority (FSA), and Indonesia's central bank. The data of banks levelled in books-3 and -4 are collected from the OSIRIS database, including companies listed on the Indonesian Stock Exchange (IDX). Meanwhile, data for banks levelled in books-1, -2 , and -3 (not listed on the IDX) are collected from the Indonesian FSA. This research documents the data for CR, LDR, ROA(E), CAR, OE-OR, and NPL, which are the conventional measurements from these databases, websites, and the IDX. They are used to examine Hypothesis H1. The data relating to the banks' financial accounting information such as total assets, loans, debts, earnings, the book value of assets, and comprehensive income is obtained from either the OSIRIS database or each bank's website. This study's data observations started in 2014 and ran to 2018. The authors believe that five periods and the study's sampling method for the data collection are sufficient to meet the research objective.

\subsection{Sampling method}

This study uses a purposive sampling method that chooses samples based on specific criteria. The criteria are as follows: First, the banks had audited financial statements from 2013 to 2018. This study could not collect the data from 2019 to 2020 due to unpublished yet and the Covid-19 pandemic. Second, the banks' accounting period ended on 31 December. Third, the banks did not terminate their main operational activities between 2013 and 2018, meaning they did not go bankrupt. Fourth, specifically for the rural credit banks, this study only selected rural banks with assets worth 100 billion IDR or more. Finally, the regulations of the Indonesian FSA regarding good corporate governance were followed. Rural banks whose assets were below 80 billion IDR are not required to have an audit and risk monitoring committee.

\subsection{Variable measurement: Conventional}

This research employed all the conventional measurements to examine the IBA's structure. All traditional measurements are required by the Central Bank of Indonesia and those that the regulator uses to measure banks' performance. The cash ratio measures the short-term liquidity of banks (Gibson, 2012). McGoldrick and Andre (1997) defined the loan to deposit ratio as how much debt can be protected by stable funding (Van den End, 2016). The return on assets (ROA) is a financial indicator that illustrates a company's ability to generate profits, while the return on equity (Zeitoun \& Warner, 2006) is the annual 
profit after tax relating to equity. The capital adequacy ratio (CAR) measures the ability of a bank's equity capital to absorb losses. CAR calculates the amount of capital held in comparison to the risk-weighted assets. The OE-OR ratio compares operating costs with operating income to measure the level of efficiency of a bank's operations. Finally, the non-performing loan (NPL) ratio is a ratio that describes the status of problem loans in comparison to outstanding Credit.

$$
\begin{aligned}
& C R_{i, t}=\frac{\text { Cash }+ \text { Cash Equivalents }_{i, t}}{\text { Current Liabilities }_{i, t}} \\
& L D R_{i, t}=\frac{\text { Total Loans }_{i, t}}{\text { Total Deposits }_{i, t}} \\
& R_{i, t}=\frac{{\text { Earnings After } \text { Tax }_{i, t}}_{\text {Total Assets }} i, t}{\text { Tol }}
\end{aligned}
$$

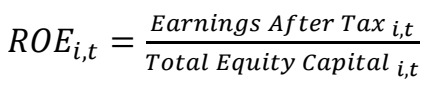

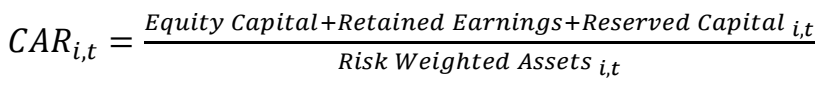

$$
\begin{aligned}
& O E-O R_{i, t}=\frac{\text { Main Operating Expenses }_{i, t}}{\text { Main Operating Revenues }_{i, t}}
\end{aligned}
$$

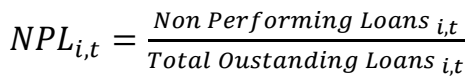

where: CR: cash ratio, LDR: loans to deposits ratio; ROA(E): return on assets (equities), CAR: capital adequacy ratio, OE-OR: operating expenses minus operating revenues, NPL: non-performing loans, i: for a firm, and t: year.

\subsection{Variable measurement: Modern financial accounting}

In the second phase, this study used modern financial analysis methods to measure the validity of the IBA's structure. First, the banks' earning power measures the ability of banks to generate contemporary returns for a certain period and subsequent periods (Chen \& Zhang, 2007; Sumiyana et al., 2010). Second, capacity is the ability of bank assets to generate profits, or the level of turnover of bank assets in generating future earnings (Chen \& Zhang, 2007; Horner \& Slesnick, 1999; Sumiyana et al., 2010). Third, investment scalability measures the ability of the assets used in the company's main production activities (Chen \& Zhang, 2007; Sumiyana et al., 2010). Fourth, the growth opportunity measures the potential for increasing the scale of operating assets in future developments (Chen \& Zhang, 2007). Finally, the discounted cost of capital is the cost, to a bank, for its ability to generate future cash inflows.

$$
\begin{gathered}
E P_{i, t}=\frac{E\left(X_{i, t+1}\right)-\left(X_{i, t}\right)}{\left(X_{i, t}\right)} \\
Q_{i, t}=\frac{\left(B V_{i, t+1}\right)-\left(B V_{i, t}\right)}{\left(B V_{i, t}\right)} \\
I S_{i, t}=\frac{\left(O S C_{i, t+1}-O S C_{i, t}\right)-\left(O S C_{i, t}-O S C_{i, t-1}\right)}{\left(\left(O S C_{i, t+1}-O S C_{i, t-1}\right) / 2\right)} \\
G O_{i, t}=\frac{\left(\left(\frac{\left(T A_{i, t+1}\right)-\left(T A_{i, t}\right)}{\left(T A_{i, t}\right)}\right)+\left(\frac{\left(s_{i, t+1}\right)-\left(s_{i, t}\right)}{\left(s_{i, t}\right)}\right)\right)}{2}
\end{gathered}
$$




$$
D C C_{i, t}=i X\left(\frac{\left(\left(\frac{\left(B V_{i, t+1}\right)}{\left(B V_{i, t}\right)}\right)+\left(\frac{\left(B V_{i, t}\right)}{\left(B V_{i, t-1}\right)}\right)\right)}{2}\right)
$$

Where: EP: earnings power, E(X): expected earnings, X: earnings, Q: capacity, BV: book value, IS: investment scalability, OSC: outstanding credits; TA: total assets; TL: total liabilities, GO: growth opportunities, S: sales from main operating activity, DC: discounted cost of capital, i: for a firm, and t: year.

\subsection{Hypotheses tests}

This study makes its analysis using the following steps. First, it measures the performance of each bank within the IBA structure using the banking ratio method, such as CR, LDR, ROA (E), CAR, OE-OR, and NPL. Second, it measures the effect of banking performance with the models developed by Chen and Zhang (2007) and Sumiyana et al. (2010), including earnings power (EP), capacity (Q), investment scalability (IS), growth opportunities (GO), and the discounted cost of capital (DCC). Third, this study compares the results of the measurements, both the conventional ones and those obtained from the modern financial accounting ratios, for each book value with an independent sample t-test.

Mean comparison tests were designed to support the validity of the IBA structure. However, this study stands on searching for the fallacy of the current IBA structure. This fallacy means that unsupported hypotheses are the main goals of this study. In other words, the unsupported hypotheses suggested that the existing IBA structure is invalid. With mathematical formulations, the invalidity of the IBA structure is when the CR, LDR, ROA (E), CAR, OE-OR, and the NPL of banks listed in Book -4 are equal to those listed in Book -3 , which are equal to those in Book -2 , which are equal to those in Book -1 . The invalidity is also supported whether the modern measurements of EP, Q, IS, GO, and DCC of banks in Book -4 are equal to those in Book -3 , Book -2 , and Book -1 or not.

\section{STATISTICAL RESULTS}

\subsection{Population and sample}

The population in this study were all international banks, national banks, regional development banks, and rural credit banks in Indonesia during the observed period from 2012 to 2018. According to Indonesian banking statistics data, released by the Indonesian FSA in 2018, there were 115 commercial banks, 88 international and national banks and 27 regional development banks. Finally, the population for the rural credit banks was 1,621 or 8,105 firm-year samples. The banks in the sample are listed in the Indonesian FSA's directory selected based on specific predetermined criteria. Research data for international banks, national commercial banks, and regional development banks were obtained from each bank's website. Meanwhile, rural credit banks' data were obtained from reports published on the Indonesian FSA'swebsite. Thus, the final number of samples that met the established criteria were 135 banks or 675 firm-year observations, with the details in Table 1 below.

\subsection{Descriptive statistics}

A descriptive analysis was performed to determine the data's variations without further examining or drawing conclusions. Instead, a descriptive analysis was carried out to facilitate the analysis process and interpret the data. Table 2 summarises the descriptive statistics in this study's research data, including 
minimum, maximum, mean, median, and standard deviations of the banking performance for the variables of the conventional measurements.

Table 1

Research sample

\begin{tabular}{|c|l|r|r|}
\hline No. & \multicolumn{1}{|c|}{ IBA Structure } & \multicolumn{1}{|c|}{ Bank Units } & \multicolumn{1}{c|}{ Firms-Years } \\
\hline 1. & International Bank - listed in Book -4 & 7 & 35 \\
\hline 2. & National Bank - listed in Book -3 & 34 & 170 \\
\hline 3. & Development Bank - listed in Book -2 & 20 & 100 \\
\hline 4. & Rural Credit - listed in Book -1 & 74 & 370 \\
\hline & Total & 135 & 675 \\
\hline
\end{tabular}

Source: own calculation

Descriptive Statistics

$\mathrm{N}=675$

\begin{tabular}{|l|r|r|r|r|r|}
\hline \multicolumn{1}{|c|}{ Measurements } & \multicolumn{1}{c|}{ Min. } & \multicolumn{1}{c|}{ Max. } & \multicolumn{1}{c|}{ Mean } & \multicolumn{1}{c|}{ Median } & Std. Dev. \\
\hline Conventional: & & & & & \\
\hline CR (Cash Ratio) & 4.3800 & 80.7500 & 19.8859 & 17.9300 & 10.7674 \\
\hline LDR (Loan to Deposit Ratio) & 26.0000 & 144.3600 & 84.5288 & 86.0000 & 14.0500 \\
\hline ROA (Return on Asset) & -11.1500 & 15.0000 & 3.0347 & 3.0000 & 2.2122 \\
\hline ROE (Return on Equity) & -83.7900 & 71.4700 & 18.7013 & 18.2800 & 14.5100 \\
\hline CAR (Capital Adequacy Ratio) & 8.0000 & 66.4300 & 20.2809 & 18.6400 & 7.4166 \\
\hline OE-OR (Operating Expenses - Revenue) & 48.1300 & 235.2000 & 80.3925 & 79.0000 & 14.3809 \\
\hline NPL (Non-Performing Loan) & 0.0400 & 15.9700 & 3.4699 & 2.7700 & 2.9242 \\
\hline Modern: & & & & & \\
\hline Earnings Power (EP) & -3041.4000 & 1392.5100 & -3.9935 & 9.2000 & 210.5250 \\
\hline Capacity (Q) & -84.8900 & 407.3900 & 17.4213 & 12.4100 & 27.7381 \\
\hline Investment Scalability (IS) & -9288.6400 & $12,095.9100$ & -11.3933 & -11.9800 & 707.5244 \\
\hline Growth Opportunities (GO) & -36.9600 & 198.6200 & 12.8169 & 11.0100 & 16.5294 \\
\hline Discounted Cost of Capital (DCC) & 3.3400 & 23.6300 & 7.3656 & 7.6800 & 2.2773 \\
\hline
\end{tabular}

Source: own calculation

Table 2 shows the results of the descriptive analysis for all the observations of 675 firm-years without considering bank clusters. The average value of CR is $19.89 \%$, and its standard deviation is $10.77 \%$. The maximum and minimum values are $80.75 \%$ and $4.38 \%$, respectively, from the Bank of Sulawesi Tengah Development and the Rural Bank of Trisurya Bumindo. It indicates that the banks' cash ratios in Indonesia are pretty varied. The second indicator is the loan to deposit ratio (McGoldrick \& Andre, 1997). Overall, the average bank LDR in Indonesia is $84.53 \%$, and the median is $86.00 \%$. The minimum value of LDR is $26 \%$ from the Rural Bank of Prima Multi Makmur, while the maximum value of LDR is $144.36 \%$ from the National Bank of KEB Hana, Indonesia. The average and standard deviation of the banks' ROA in Indonesia are 3.03\% and 2.21\%, and the banks' ROE in Indonesia is $18.70 \%$ and $14.51 \%$. This shows that the ROE data in Indonesia is quite varied. The maximum and minimum ROA values are $15 \%$ and $-11.15 \%$, and ROE values are $71.47 \%$ and $-83.79 \%$. The maximum value of ROA and ROE is obtained from the Rural Credit Bank of Dana Makmur and Universal bank, while the minimum value of ROA and ROE is yielded by the Bank of India-Indonesia and the Development Bank Banten.

The average capital adequacy ratio is $20.28 \%$, with a standard deviation of $7.42 \%$. On the other hand, the maximum CAR value of Indonesian banks reached $66.43 \%$, obtained from Bank Ina Perdana, while the minimum value of $8 \%$ came from the Rural Bank of Citra Dumoga. The ratios for the OE-OR of the Indonesian banks are $80.40 \%$, with a standard deviation of $14.38 \%$. The maximum value of OE-OR reaches $235.2 \%$, which is Bank of India-Indonesia, and the minimum value of $48.13 \%$ is from the Bank Panin. It 
shows that the Panin bank is the most efficient in managing its operational costs. The NPL ratios from 2013 to 2017 were $3.47 \%$, with a standard deviation of $2.78 \%$. BCA achieved the minimum NPL value of $0.04 \%$, and the Rural Bank of Barelang, Mandiri, obtained the maximum value of $15.97 \%$. It shows that the number of bad loans is relatively high at the Rural Bank of Barelang, Mandiri.

From the perspective of modern measurements, the earning power for banks in Indonesia has an average of $-3.98 \%$, with a standard deviation of $210.52 \%$. However, it shows that the banks' profits from 2013 to 2017 varied greatly. The lowest-earning power of $-3041.4 \%$ was obtained from Bank Permata, and Bank SBI Indonesia achieved the highest of $1392.51 \%$. Indonesian banks have an average value of $17.42 \%$ in terms of capacity, with the highest value of $407.39 \%$ being achieved by Bank Ganesha and the lowest value of $-84.89 \%$ recorded by Bank Mega. The average value of the investment scalability of banks in Indonesia from 2013 to 2017 was $-11.39 \%$, with a standard deviation of $707.52 \%$. The Rural Bank of Kerta Raharja obtained the minimum investment scalability value of $-9288.64 \%$, and the Bank of Rabobank Indonesia achieved the maximum value of $12,095.91 \%$. The average growth opportunities are $12.82 \%$, with a standard deviation of $16.53 \%$; the maximum and minimum growth opportunities are $198.62 \%$ and $36.96 \%$ obtained from Bank Mandiri, Taspen, and the Development Bank of Banten. The last indicator is the discounted cost of capital. The average discounted cost of capital for the 675 observations is $7.37 \%$, with a standard deviation of 2.28\%. The lowest discounted cost of capital is 3.34\%, achieved by Bank BPD DIY, and Bank Ganesha has the highest value, 23.63\%. It indicates that Bank BPD DIY is good enough to manage its interest risk.

\subsection{Mean comparison results: Conventional measurements}

Table 3 shows the statistical test results for $\mathrm{H1}$ a, which are that the mean difference between Book -4 and Book -3 banks is not significant. The difference in the mean CR of Book -3 and Book -2 is also not significant, and even the CR of Book -2 outperforms Book -3. It shows that the performance of regional development banks (Book -2) is better than that of the international and national banks in terms of CR. The statistically significant differences for the CR only occurred between the Book -2 and Book -1 banks, so that the Hypothesis H1a is not supported. Similar results also appear for H1b, where the mean differences between books -4 and -3 , and books -3 and -2 are insignificant. Furthermore, Table 3 shows that the highest LDR of Book -2 is far above that of Book -1. Therefore, Hypothesis H1b is not supported.

Testing Hypothesis H1c, which focuses on ROA and ROE, produces mean differences significant in comparing Book -2 and Book -1. It meant that Hypothesis H1c is not supported. Based on the tests, the highest statistical mean of ROA and ROE is Book - 1 for rural credit banks. It shows that only possessing a small amount of capital or assets does not prevent rural credit banks from producing high levels of profitability. Tests for H1d show no significant difference between the CAR comparisons of books-1 and 2, books-2 and -3 , or books-3 and -4 . Therefore, it could be concluded that Hypothesis H1d is not supported. In the OE-OR comparisons, Book -3 and Book -1 have the highest mean of OE-OR. It indicates that Book -3 lists banks with the lowest levels of efficiency. For the NPL, Book -1 lists the banks with the highest mean for NPL. It shows that the banks listed in Book -1 still conduct risky lending and have poor credit management. Testing the hypotheses $\mathrm{H} 1 \mathrm{a}$ to $\mathrm{H} 1 \mathrm{f}$ briefly found no significant differences. This statistical test shows that international banks (Book -4) failed to better perform than national, regional development, or rural credit banks. This study inferred that the conventional measurements did not support the evidential matter of the IBA's structure. It, therefore, meant that the current IBA is relevant and can describe the performance and risk of each type of bank. 
Table 3

Mean Comparison Results for Conventional Measurements

\begin{tabular}{|c|c|c|c|c|c|c|}
\hline \multicolumn{2}{|c|}{ Hypotheses } & \multicolumn{2}{|c|}{ Mean } & Mean Diff. & t-Value & Sig. \\
\hline \multirow{3}{*}{$\begin{array}{l}\text { CR; } \\
\text { H1a }\end{array}$} & Book $-4>$ Book -3 & 20.5769 & 20.3379 & 0.2389 & 0.1760 & \\
\hline & Book -3 > Book -2 & 20.3379 & 27.7062 & -7.3683 & -5.972 & \\
\hline & Book -2 > Book -1 & 27.7062 & 17.4993 & 10.2069 & 8.065 & *** \\
\hline \multirow{3}{*}{$\begin{array}{r}\text { LDR; } \\
\text { H1b }\end{array}$} & Book -4 > Book -3 & 88.0366 & 88.1677 & -0.1311 & -0.0510 & \\
\hline & Book $-3>$ Book -2 & 88.1677 & 95.7319 & -7.5642 & -4.406 & \\
\hline & Book $-2>$ Book -1 & 95.7319 & 79.4971 & 16.2348 & 11.769 & $* * *$ \\
\hline \multirow{3}{*}{$\begin{array}{l}\text { ROA; } \\
\text { H1c }\end{array}$} & Book -4 > Book -3 & 2.7891 & 1.0771 & 1.7120 & 5.335 & *** \\
\hline & Book -3 > Book -2 & 1.0771 & 2.6219 & -1.5448 & -6.742 & \\
\hline & Book -2 > Book -1 & 2.6219 & 4.0689 & -1.4470 & -6.8890 & \\
\hline \multirow{3}{*}{$\begin{array}{r}\text { ROE; } \\
\text { H1c }\end{array}$} & Book -4 > Book -3 & 16.5826 & 6.2614 & 10.3212 & 5.010 & *** \\
\hline & Book $-3>$ Book -2 & 6.2614 & 19.5537 & -13.2924 & -8.009 & \\
\hline & Book -2 > Book -1 & 19.5537 & 24.387 & -4.8333 & -3.3140 & \\
\hline \multirow{3}{*}{$\begin{array}{r}\text { CAR; } \\
\text { H1d }\end{array}$} & Book $-4>$ Book -3 & 18.7803 & 20.4718 & -1.6915 & -1.318 & \\
\hline & Book -3 > Book -2 & 20.4718 & 20.6703 & -0.1985 & -0.2300 & \\
\hline & Book -2 > Book -1 & 20.6703 & 20.2299 & 0.4404 & 0.5120 & \\
\hline \multirow{3}{*}{$\begin{array}{l}\text { OE-OR; } \\
\text { H1e }\end{array}$} & Book $-4<$ Book -3 & 72.9783 & 90.7757 & -17.7974 & -5.368 & $* * *$ \\
\hline & Book $-3<$ Book -2 & 90.7757 & 77.5414 & 13.2343 & 5.8360 & \\
\hline & Book $-2<$ Book -1 & 77.5414 & 77.0987 & 0.4427 & 0.3820 & \\
\hline \multirow{3}{*}{$\begin{array}{l}\text { NPL; } \\
\text { H1f }\end{array}$} & Book $-4<$ Book -3 & 2.3377 & 2.7325 & -0.3948 & -1.080 & \\
\hline & Book $-3<$ Book -2 & 2.7325 & 2.5462 & 0.1863 & 0.7120 & \\
\hline & Book $-2<$ Book -1 & 2.5462 & 4.1654 & -1.6192 & -4.5960 & $* * *$ \\
\hline
\end{tabular}

Note: $*$ indicates significance level at 0.10 level, **at 0.05 level, ***at 0.01 level.

Source: own calculation

\subsection{Mean comparison results: Modern measurements}

Table 4 shows no significant difference between the types of banks when measuring earning power (EP) in the investigation of Hypothesis H2a. The highest mean of EP is not found in Book -4 but Book -1. It shows that the highest ability to make a profit is Book -1. Testing Hypothesis H2b on the capacity (Q) of the four types of banks in the IBA's structure is only significant for the mean differences in Book -3 and Book -2. The highest mean for Q is Book -3. Therefore, it shows that Hypothesis H2b is not supported. Testing hypotheses $\mathrm{H} 2 \mathrm{c}$ andH2d show no significant mean differences between the banks listed in Book-4, Book -3, Book -2, and Book -1 consecutively. Based on the statistical results, it can be concluded that there are no significant differences in terms of investment scalability (IS), growth opportunity (GO), and the discounted costs of capital (DCC) among the different banks. The statistical results of hypotheses H2a to H2e show no significant mean differences between each type of bank, using the modern measurements of earning power, capacity, investment scalability, growth opportunity, and the discounted cost of capital. It identified that the current IBA's structure can still not describe the performance and risks for each type of bank.

\section{DISCUSSION AND ANALYSIS}

This study found that all 11 hypotheses were not supported. The mean comparison tests did not support any of the hypotheses. Therefore, the current IBA's structure has no validity. It means that banks in Book $-1,-2,-3$, and -4 did not have a levelled structure in their earning, capacity, size, risk, etc. Therefore, this study demonstrates that the existing IBA's structure did not have validity due to its incoherence for the purposes of comparability and understandability. In modern measurements, the current IBA is not built with a logical structure, and it cannot distinguish between which banks potentially have growth 
opportunities, earning power, scalability, and efficient operations. This research inferred that the performance measurements issued by the Central Bank of Indonesia and the Indonesian FSA are not related to the IBA's structure on a single axis. In other words, the current IBA's structure would be meaningless, whether it is still implemented in the future or not. It did not facilitate and predict the banks' abilities to reach their future prospective performance targets in the banking industry (Liu et al., 2018; Stiles \& Kaplan, 2004). With a single-axis structure, the IBA, as it stands, does not consider many conditional factors that affect the industry (Liu et al., 2018). This study concludes that the structure of the existing IBA is a weakness, and it does not characterize industrial banking in Indonesia. Moreover, it infers that the current IBA structure could not facilitate and support each bank's self-evaluation (Goethals, 1986; Ogden \& Venkat, 2001; Suls et al., 2002) used to enhance performance in the industry.

Table 4

Mean Comparison Results for Modern Measurements

\begin{tabular}{|c|c|c|c|c|c|c|}
\hline \multicolumn{2}{|c|}{ Hypotheses } & \multicolumn{2}{|c|}{ Mean } & Mean Diff. & t-Value & Sig. \\
\hline \multirow{3}{*}{$\begin{array}{l}\text { EP; } \\
\text { H2a }\end{array}$} & Book $-4>$ Book -3 & 11.3000 & -49.1676 & 60.4676 & 0.8700 & \\
\hline & Book $-3>$ Book -2 & -49.1676 & 6.6681 & -55.8357 & -1.3570 & \\
\hline & Book $-2>$ Book -1 & 6.6681 & 12.4523 & -5.7842 & -1.1430 & \\
\hline \multirow{3}{*}{$\begin{array}{l}\mathrm{Q} ; \\
\mathrm{H} 2 \mathrm{~b}\end{array}$} & Book $-4>$ Book -3 & 14.7811 & 21.2764 & -6.4952 & -0.8740 & \\
\hline & Book $-3>$ Book -2 & 21.2764 & 14.5025 & 6.7739 & 1.4060 & $*$ \\
\hline & Book $-2>$ Book -1 & 14.5025 & 16.6886 & -2.1861 & -0.9640 & \\
\hline \multirow{3}{*}{$\begin{array}{l}\text { IS; } \\
\text { H2c }\end{array}$} & Book $-4>$ Book -3 & -47.8669 & 16.8563 & -64.7232 & -0.3550 & \\
\hline & Book $-3>$ Book -2 & 16.8563 & 9.3547 & 7.5016 & 0.0700 & \\
\hline & Book $-2>$ Book -1 & 9.3547 & -26.5301 & 35.8848 & 0.5790 & \\
\hline \multirow{3}{*}{$\begin{array}{l}\mathrm{GO} ; \\
\mathrm{H} 2 \mathrm{~d}\end{array}$} & Book $-4>$ Book -3 & 8.0306 & 14.9068 & -6.8763 & -1.660 & \\
\hline & Book $-3>$ Book -2 & 14.9068 & 10.3684 & 4.5384 & 1.7290 & $* *$ \\
\hline & Book $-2>$ Book -1 & 10.3684 & 12.9713 & -2.6029 & -1.7560 & \\
\hline \multirow{3}{*}{$\begin{array}{r}\text { DCC; } \\
\text { H2e }\end{array}$} & Book $-4<$ Book -3 & 7.1149 & 7.6571 & -0.5423 & -1.0770 & \\
\hline & Book $-3<$ Book -2 & 7.6571 & 7.1867 & 0.4704 & 1.4310 & \\
\hline & Book $-2<$ Book -1 & 7.1867 & 7.3038 & -0.1171 & -0.5050 & \\
\hline
\end{tabular}

Note: $*$ indicates significance level at 0.10 level, **at 0.05 level, ***at 0.01 level.

Source: own calculation

Due to the inability to characterize the industry, this study continues to criticize the current IBA because it does not utilize the rules and resources to organize the industrial systems' properties. It means that the structuring of industrial systems occurred when the Indonesian banking industry declared its readiness for change (Coad \& Herbert, 2009; Giddens, 1984). In other words, the current IBA has a low structuration process (Coad \& Herbert, 2009; Englund \& Gerdin, 2014; Giddens, 1984) with its statical structure on a single axis. This low structuration process could be explained by the current IBA not supporting the interpretative schemes, facilities, and norms. It means that the Central Bank of Indonesia should have facilitated the big rural banks in Indonesia to operate as either national banks or international banks. It also means that a robust IBA structure could facilitate each bank to empower itself in the industrial arena. Consequently, either the Central Bank of Indonesia or the Indonesian FSA have to make the IBA's structure, which each bank could use to transform and move into the industrial class (Coad \& Herbert, 2009; Giddens, 1984). From the Indonesian banking industry's perspective, the IBA's structure itself should have its dynamic structuration, meaning that the process for achieving transformability could be easily practised.

This research conducted its hypotheses testing twice. The results are consistent and show that both the conventional and modern measurements of banking performance do not support the book values in the IBA's structure. Therefore, the idea that the structure of the banks in Book -4 is better than those in Book 
-3 , and those are better than the ones in Book -2 , and they are better than the banks in Book -1 is not valid. Aside from this, the risks of the banks in the books are also not valid. It means that the current IBA's structure did not consider the banks' performances and risks. This study, furthermore, took into account (OJK, 2017) that the existing IBA's structure is supposed to create a sound banking structure, an effective regulatory system, an independent and effective supervision system, a strong banking industry, adequate supporting infrastructure and consumer protection. It then argues that Bank Indonesia could not empower the banking industry with an over-generalization structure on a single axis. Furthermore, all the banking performance and risk measurements could not explain or prove that the IBA's structure is valid for the books' values. This study, therefore, inferred that the Central Bank of Indonesia, as the highest authority, could not optimally control, supervise, and monitor the banking industry due to the over-simplified structure of the IBA. Therefore, it recommends that a new IBA structure should be developed with the primary function of both understandability and comparability.

\subsection{Findings: The need for a new IBA structure}

This study noted that the Central Bank of Indonesia, and the design for the IBA, has to empower the banking structure, provide an effective regulatory system, have an independent and effective supervision system, create a robust banking industry, and have the adequate supporting infrastructure and consumer protection (OJK, 2017). Meanwhile, this study argues that the current IBA structure does not support these functions, authorities, and responsibilities as the regulation requires. This study presents evidence of the existing IBA structure, which is not supported by the banks' performance and risk measurements. Furthermore, it demonstrates that the current IBA's structure does not facilitate control, supervision, and monitoring. In other words, this study discloses that the IBA's structure is somehow over-generalized due to its simplified construction. It consequently recommends that the existing IBA structure be transformed into a new one that the Central Bank of Indonesia could use to help the banking industry develop its adaptive structuration and dynamic capabilities.

The validity of the IBA's structure is only seen in its empowerment to conduct adaptive structuration (Coad \& Herbert, 2009; Englund \& Gerdin, 2014; Giddens, 1984) and dynamic capability-building (Aramand \& Valliere, 2012; Liu et al., 2018; Tseng \& Lee, 2014) for each bank and the banking industry as a whole in Indonesia. From the perspective of adaptive structuration, the existing structure should be empowered to reproduce a new structure with industrial systems properties. It means that if a bank joins the Indonesian banking industry, it adopts the adaptive capability when it knows its position. It also means that a bank could transform itself into the intra-industrial class. For the regulator, this research argues that, whether the current IBA'structure has a valid construction or not, the Central Bank of Indonesia could engineer the transformation process of the banking industry. The existing IBA did not facilitate each bank in the banking industry from the dynamic capability to maximize its discretion due to the fixed book. A bank could develop its dynamic capability if it has legitimate control to compare itself with others in the banking industry. It would learn by comparing itself to the banking industry (Liu et al., 2018; Stiles \& Kaplan, 2004). This bank, therefore, could modify its resources to operate in the industrial class. This study inferred that the existing IBA could not identify the position of a bank in the Indonesian banking industry. This study figured that whether the Central Bank of Indonesia would facilitate all banks to optimize their resources or not, the Central Bank of Indonesia should empower each bank to devote itself to achieving organizationally dynamic capability. It could be achieved when the Central Bank of Indonesia creates a new IBA structure, in which each bank could compare itself with the other banks dynamically and continuously.

This study recommends that the existing IBA's structure be transformed into a new one, using the matrix's function, such as the general electric model. It means that the Central Bank of Indonesia conducts 
the need for transformation to increase decision-making relevance. The current structure describes the bank's size, which is based on its capital or assets only. In this new IBA structure, two axes display a bank's position in the Indonesian banking industry. A bank, therefore, knows its position in the industry, and it could transform itself in a vector direction, which is not a scalar one (Hax \& Majluf, 1983; Liu et al., 2018). It would be an efficient strategy for when a bank enters the Indonesian banking industry and acknowledges its position. For the regulator, whether the new IBA is employed or not, the Central Bank of Indonesia could highlight the worst and the best banks' performances. Thus, it facilitates the Central Bank of Indonesia's control, supervision, and monitoring of the banking system. On the other hand, the Central Bank of Indonesia, with the new IBA, has auditing tools for understanding and comparing the intra-banking industry. The most excellent use of the new IBA is that the Central Bank of Indonesia could conduct an industrial transformation process due to having a performance and risk dashboard for the decision-making process.

This article presents, as examples, two designs to clarify the clearness of the new IBA's structure. The first design is an IBA structure with the matrices of the horizontal axis used for the LDR (loan to deposit ratio) and the vertical one used to show EP (earnings power). The second one has the matrices of the horizontal axis for Q (capacity) and the vertical axis for the GO (growth opportunities) - Pictures 1 and 2 present the new IBA's structure in several models below.

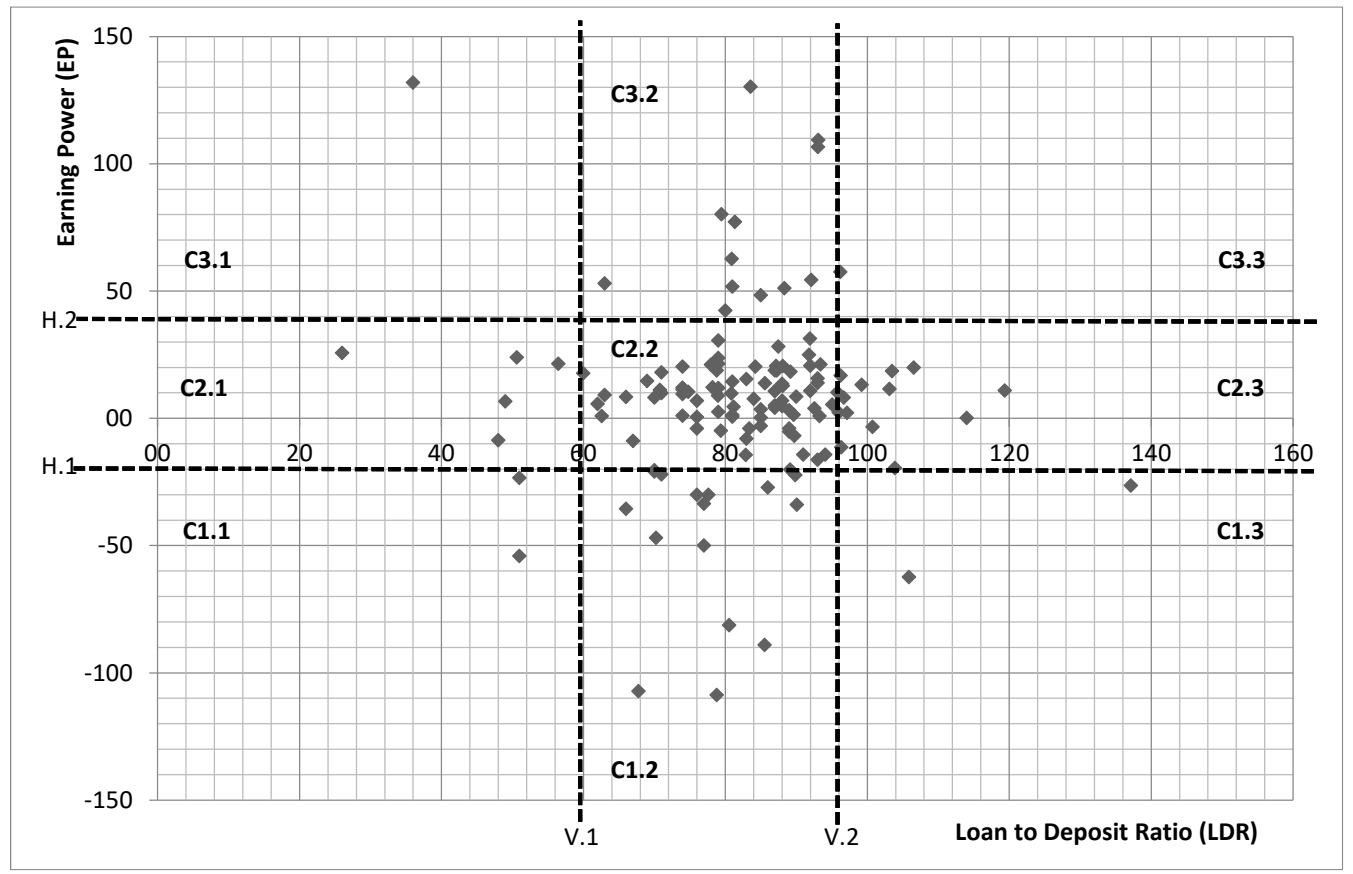

Figure 1. The New IBA Structure - Model 1

Source: own compilation

Figure 1 and 2 present the new IBA's structure. The Central Bank of Indonesia could also design many pictures for comprehending the new IBA's structure. It should be noted that the division axes of V.1, V.2, H.1, and H.2 are intuitive picturing. This study infers that Picture 1 displays arrays of banks ignoring the levelled books in the current IBA structure. It formulates the banks' LDR and EP structure using the General Electric Model, which produces nine cells for measuring their performance. The Indonesian regulators understand some banks are in a worse position (cell: C1.1). Other cells explain the powers of each bank's LDR (loan to deposit ratio) and EP (earnings power). This study, therefore, inferred each bank's 
position in the Indonesian banking industry. Then the Indonesian regulators could take a strategic decision to transform the banks in cell C1.1 into better ones. Picture 2 also recommends the same strategic decisions to the Indonesian regulator, regardless of if the many banks in cell C1.1 are the worst banks for their Q (capacity) and GO (growth opportunities), or not. Then, it would be easy enough to make a policy for the banks to be transformed into better ones, in which the Central Bank of Indonesia and the Indonesian FSA could either help to upgrade them or terminate them. From the bank's perspective, it could internalize its position and conduct an industrial comparison because it knows its position and description.

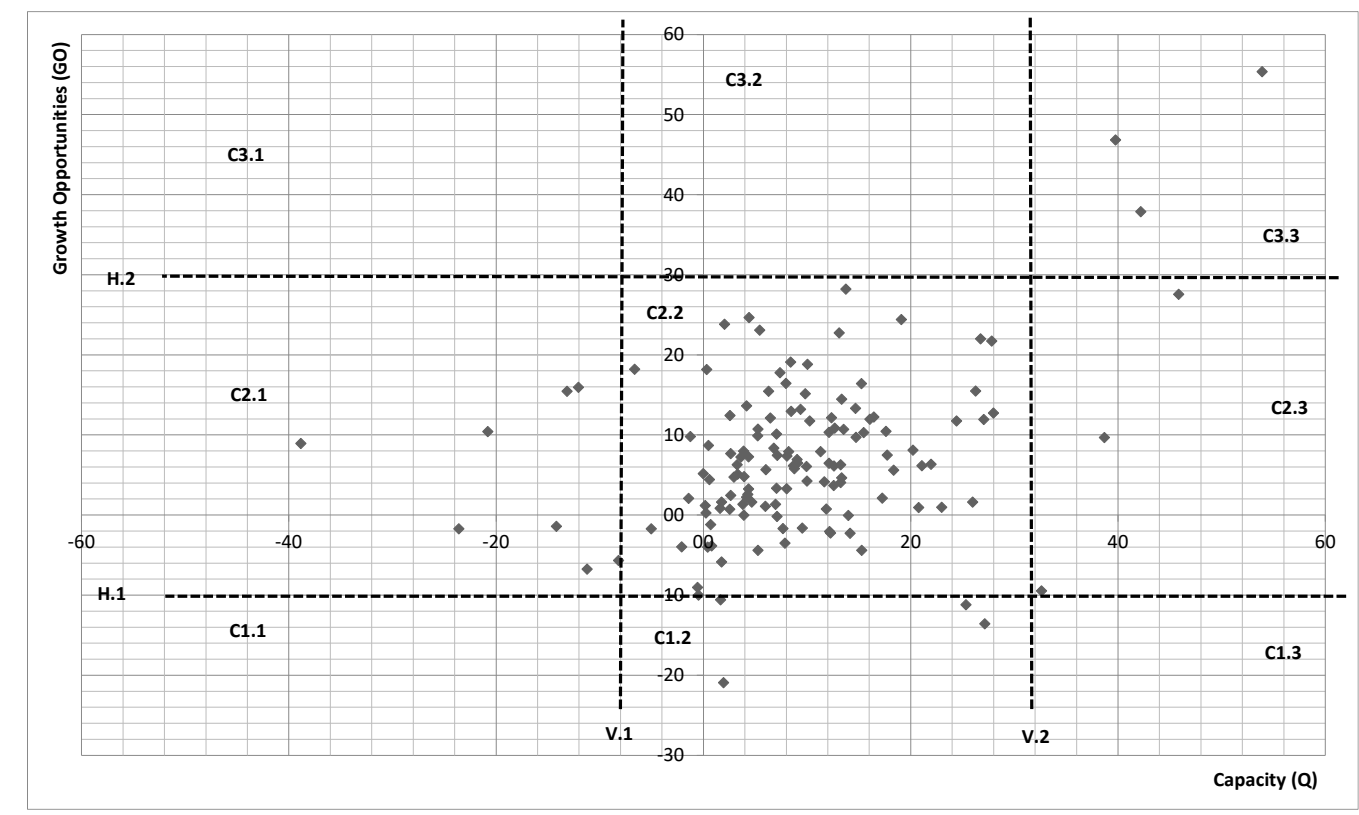

Figure 2. The New IBA Structure - Model 2

Source: own compilation

The latest findings of this study are that the new IBA's structure is not a static book. However, the new IBA has to be adynamic book periodically, systematically, and be updated in real-time. This study argues that the new IBA's structure accommodates dynamic improvements for each bank. It clearly explains that a bank in cell C2.1 in one year could shift to cell 2.3 due to its business strategy. The danger is that those banks in cell C3.1 in a particular year could fall into cell C1.3 because of their inability to compete in the banking industry. This study, therefore, infers that the new IBA's structure could educate each bank in the Indonesian banking industry to be adaptive, dynamic, and agile. In other words, this new IBA's structure supports each bank to conduct its business with adaptive structuration, dynamic capability, and business agility. Furthermore, this study could argue that the new IBA's structure makes chief executive officers of banks in Indonesiaaware of their positions, stimulating them to learn about each other. It concludes that the new IBA's structure excites bank officers when they are conducting social cognition.

\section{CONCLUSIONS, LIMITATIONS AND FUTURE RESEARCH}

This study examined the suitability of the Indonesian Banking Architecture (IBA) structure based on conventional and modern performance measurements. The results of this study show that, based on the traditional measurements consisting of CR, LDR, ROA, ROE, CAR, OE-OR, and NPL, there is no evidence of either a dominant performance or a low risk in Book -4 in comparison with books-3, -2 and 1 , as illustrated by the current IBA's structure. The modern measurements consisting of earning power, 
capacity, investment scalability, growth opportunity, and discounted cost of capital also did not provide evidence of a dominant performance or a low risk in Book -4 as described by the existing IBA's structure. This research shows that the structure represented by the existent IBA could not explain the performance and risk levels for each bank. Based on the structuration theory, the new IBA's structure should always change by following each bank's performance and risk. Therefore, the inability of the current IBA to describe the performance and risk of a bank indicates the low capability of the IBA's structure.

This study is expected to empower the Indonesian regulator by finding that a new IBA structure would be needed and relevant for future decision-making. It proposes using either the nine-cell general electric or the McKinsey matrix based on a minimum of two performance or risk measurements. By transforming itself into a nine-cell matrix, the new IBA's structure could identify, analyze, and acknowledge the development of each bank, and its position, in the Indonesian banking industry. This new IBA structure also supports and then accommodates each bank to conduct its business in an adaptive structuration and dynamic capability system. By these means, bank officers in Indonesia would learn social cognition. This research also generates relevant inputs for the Indonesian FSA to regulate, supervise, and control all the banks in Indonesia. Whether the Indonesian FSA found a chaotic bank or not, the new IBA's structure could be used to transform this bank immediately. Therefore the new IBA's structure could provide and describe reliable information for Indonesian decision-makers.

This study has several limitations. First, this study could not capture the effects of currency volatility on the financial statements of banks. Most international banks are affected, to some degree, by the United States dollar, but rural credit banks are not. The Indonesian rupiah's exchange rate against the US dollar can move swiftly. This research also explains that the Indonesian rupiah tends to depreciate annually. It means that the banks listed in Book -4 are affected by the rupiah's depreciation to a greater extent than the banks listed in books-1 and -2. This study could not anticipate the influence of the exchange rate in its statistical analysis. Second, there is a possibility of sample selection bias. Banks in Book -1, which lists rural credit banks, are missing data. This study could only acquire the data of rural credit banks from the Indonesian FSA publications. It used a sample from Book -1 whose assets had reached 100 billion rupiahs. This study used 254 rural credit banks based in Indonesia, only 15\% of the total banks in Book -1. Third, this research has not differentiated between banks' performance and risks, based on their equity's ownership, which is either government or privately held. The banks in Book -2 are the banks with majority ownership by the regional state governments. Future studies can probably expand to examine the banks' performance and risks by distinguishing between the equity's ownership.

\section{ACKNOWLEDGEMENT}

This article is a further arrangement and methodological refinement of the second author's thesis in the Master of Science and Doctorate Programmes, Faculty of Economics and Business, University of Gadjah Mada. This article has been presented three times in an internal seminar forum at the Faculty of Economics and Business, University of Gadjah Mada. The authors appreciate all participants' critics and comments and the supports from this programme.

\section{REFERENCES}

Aramand, M., \& Valliere, D. (2012). Dynamic capabilities in entrepreneurial firms: A case study approach. Journal of International Entrepreneurship, 10(2), 142-157. https://doi.org/10.1007/s10843-012-0088-3

Bhatia, V. K. (1997). Democratizing government decision-making: A study of public discourse in Hong Kong. Journal of Pragmatics, 28(4), 515-532. https://doi.org/https://doi.org/10.1016/S0378-2166(97)00035-0

Bradshaw, M. T., Richardson, S. A., \& Sloan, R. G. (2006). The relation between corporate financing activities, analysts' forecasts and stock returns. Journal of Accounting and Economics, 42(1), 53-85. https://doi.org/https://doi.org/10.1016/i.jacceco.2006.03.004 
Chen, P., \& Zhang, G. (2007). How do accounting variables explain stock price movements? Theory and evidence. Journal of Accounting and Economics, 219-244. https://doi.org/https://doi.org/10.1016/j.jacceco.2007.01.001

Coad, A. F., \& Herbert, I. P. (2009). Back to the future: New potential for structuration theory in management accounting research? Management Accounting Research, 20(3), 177-192. https://doi.org/https://doi.org/10.1016/j.mar.2009.02.001

Cohen, D. A., \& Lys, T. Z. (2006). Weighing the evidence on the relation between external corporate financing activities, accruals and stock returns. Journal of Accounting and Economics, 42(1), 87-105. https://doi.org/https://doi.org/10.1016/j.jacceco.2006.04.006

DeSanctis, G., \& Poole, M. S. (1994). Capturing the Complexity in Advanced Technology Use: Adaptive Structuration Theory. Organization Science, 5(2), 121-147. https://doi.org/https://doi.org/10.1287/orsc.5.2.121

Englund, H., \& Gerdin, J. (2014). Structuration theory in accounting research: Applications and applicability. Critical Perspectives on Accounting, 25(2), 162-180. https://doi.org/https://doi.org/10.1016/i.cpa.2012.10.001

Festinger, L. (1954). A theory of social comparison processes. Human Relations, 7(2), 117-140. https://doi.org/https://doi.org/10.1177/001872675400700202

Gibson, C. H. (2012). Financial reporting and analysis. Cengage Learning.

Giddens, A. (1984). The constitution of society: Outline of the theory of structuration. Univ of California Press.

Goethals, G. R. (1986). Social Comparison Theory: Psychology from the Lost and Found. Personality and Social Psychology Bulletin, 12(3), 261-278. https://doi.org/10.1177/0146167286123001

Hax, A. C., \& Majluf, N. S. (1983). The Use of the Industry Attractiveness-Business Strength Matrix in Strategic Planning. INFORMS Journal on Applied Analytics, 13(2), 54-71. https://doi.org/10.1287/inte.13.2.54

Higham, N. J. (2008). Functions of matrices: theory and computation. SIAM.

Horner, S. M., \& Slesnick, F. (1999). The Valuation of Earning Capacity Definition, Measurement and Evidence. Journal of Forensic Economics, 12(1), 13-32. https://doi.org/10.5085/0898-5510-12.1.13

Liu, C., Park, E., Jin, Y., Liu, J., Yu, Y., Zhang, W., Lei, S., \& Hu, W. (2018). Surface-Confined Dynamic Covalent System Driven by Olefin Metathesis. Angewandte Chemie International Edition, 57(7), 1869-1873. https://doi.org/10.1002/anie.201711040

McGoldrick, P. J., \& Andre, E. (1997). Consumer misbehaviour. Journal of Retailing and Consumer Services, 4(2), 73-81. https://doi.org/10.1016/S0969-6989(96)00027-6

McKinsey. (2008, 16.00). Enduring Ideas: The GE-McKinsey nine-box matrix. Mckinsey And Company. Retrieved 4 February 2020 from https://www.mckinsey.com/business-functions/strategy-and-corporate-finance/ourinsights/enduring-ideas-the-ge-and-mckinsey-nine-box-matrix\#

Ogden, H. J., \& Venkat, R. (2001). Social comparison and possessions: Japan vs Canada. Asia Pacific Journal of Marketing and Logistics, 13(2), 72-84. https://doi.org/10.1108/13555850110764775

OJK. (2017, 16.32). Arsitektur Perbankan Indonesia. Otoritas Jasa Keuangan. Retrieved 09 Agustus 2019 from https://www.ojk.go.id/id/kanal/perbankan/arsitektur-perbankan-indonesia/Pages/Struktur-Perbankan.aspx

Poole, M. S., \& DeSanctis, G. (1990). of Group Decision Support Systems: The Theory of Adaptive Structuration. Organizations and communication technology, 173.

Scott Poole, M., \& DeSanctis, G. (1992). Microlevel Structuration in Computer-Supported Group Decision Making. Human Communication Research, 19(1), 5-49. https://doi.org/10.1111/j.1468-2958.1992.tb00294.x

Stiles, B. L., \& Kaplan, H. B. (2004). Adverse Social Comparison Processes And Negative Self-Feelings: A Test Of Alternative Models. Social Behavior and Personality: an international journal, 32(1), 31-44. https://doi.org/10.2224/sbp.2004.32.1.31

Suls, J., Martin, R., \& Wheeler, L. (2002). Social Comparison: Why, With Whom, and With What Effect? Current Directions in Psychological Science, 11(5), 159-163. https://doi.org/10.1111/1467-8721.00191

Sumiyana, S., Baridwan, Z., Sugiri, S., \& Hartono, J. (2010). Accounting Fundamentals and the Variation of Stock Price: Factoring in the Investment Scalability. Gadjah Mada International Journal of Business, 12(2), 189. https://doi.org/10.22146/gamaijb.5508

Thomson, W. T. (2018). Theory of vibration with applications. CrC Press. 
Tseng, S.-M., \& Lee, P.-S. (2014). The effect of knowledge management capability and dynamic capability on organizational performance. Journal of Enterprise Information Management, 27(2), 158-179. https://doi.org/10.1108/JEIM-05-2012-0025

Van den End, J. W. (2016). A macroprudential approach to address liquidity risk with the loan-to-deposit ratio. The European Journal of Finance, 22(3), 237-253. https://doi.org/10.1080/1351847X.2014.983137

Weiss, D., Naik, P. A., \& Tsai, C.-L. (2008). Extracting Forward-Looking Information from Security Prices: A New Approach. The Accounting Review, 83(4), 1101-1124. https://doi.org/10.2308/accr.2008.83.4.1101

Zeitoun, M., \& Warner, J. (2006). Hydro-hegemony - a framework for analysis of trans-boundary water conflicts. Water Policy, 8(5), 435-460. https://doi.org/10.2166/wp.2006.054

Zhang, G. (2000). Accounting information, capital investment decisions, and equity valuation: Theory and empirical implications. Journal of Accounting Research, 38(2), 271-295. https://doi.org/https://doi.org/10.2307/2672934 